\section{Relative Performance of Strawberry Cultivars and Native Hybrids on Fumigated and Nonfumigated Soil in Michigan}

\author{
James F. Hancock ${ }^{1}$, Peter W. Callow, and Sedat Serçe \\ Department of Horticulture, Michigan State University, East Lansing, \\ MI 48824-1325
}

\section{Annemiek C. Schilder \\ Department of Botany and Plant Pathology, Michigan State University, East Lansing, MI 48824}

Additional index words. Fragaria $\times$ ananassa, black root rot complex, Idriella lunata, Pythium sp., Rhizoctonia sp., root-knot nematode, Meloidogyne hapla, methyl bromide, chloropicrin

\begin{abstract}
The performance of four California and 11 eastern cultivars of Fragaria Xananassa Duchesne in Lamarck, and 12 elite $F_{1}$ hybrids of Fragaria Xananassa with $F$. virginiana Miller in their immediate background was evaluated in a producer's field with and without methyl bromide-chloropicrin fumigation. Averaged across all genotypes, plants in nonfumigated soils had $43 \%$ fewer runners, $18 \%$ smaller fruit, and $46 \%$ lower yields than did plants on fumigated soil. They also had an average of $27 \%$ fewer crowns, 49\% more root discoloration, significantly fewer fine roots, and showed symptoms of the black root rot syndrome. The most commonly isolated pathogens from discolored roots were Pythium sp., Rhizoctonia sp.,Idriella lunata P.E. Nelson \& K. Wilh., and the root-knot nematode (Meloidogyne hapla Chitwood). The performance of all genotypes was enhanced by fumigation, although the $F$. virginiana hybrids performed comparatively better than the other cultivars on nonfumigated soils.
\end{abstract}

With the impending ban on methyl bromide fumigation, there is renewed concern about the resistance of modern strawberry cultivars to soilborne pathogens. Recent evaluations of the Univ. of California, Davis, breeding population uncovered little resistance to nonspecific soilborne pathogens found in strawberry fields. In fact, both runner production (Larson and Shaw, 1995) and fruit yield were more than doubled by fumigation (Larson and Shaw, 1996; Shaw and Larson, 1999). These reductions occurred in the absence of any of the major root or crown diseases commonly known to affect strawberries, suggesting that the negative effects were due to nonspecific, sublethal root pathogens or deleterious rhizosphere colonizers (Xiao and Duniway, 1998a, 1998b). However, no attempt was made to identify possible pathogens associated with the observed effects.

Eastern cultivars supposedly perform better on nonfumigated soils than do California cultivars, but most of the comparative studies have been done on sites with little

\footnotetext{
Received for publication for 31 Mar. 2000. Accepted for publication 23 July 2000. We thank Fred Warner for nematode counts, John Rogers for pathogen identification and Jeri Gillett for general helpful support. The cost of publishing this paper was defrayed in part by the payment of page charges. Under postal regulations, this paper therefore must be hereby marked advertisement solely to indicate this fact.

${ }^{1}$ To whom requests for reprints should be addressed. E-mail address: hancock@pilot.msu.edu
}

Horticultural Research Farm in East Lansing. All nursery fields were fumigated before planting. The plants were set in alternate parcels of soil that had either not been fumigated or had been preplant treated with a mixture of 2 methyl bromide : 1 chloropicrin (weight : weight) injected at a rate of $392 \mathrm{~kg} \cdot \mathrm{ha}^{-1}$. Plants were established in double rows at 40$\mathrm{cm}$ spacing, in a randomized block design with four replicates of four plants for each soil/genotype treatment. The plots received no fungicide or pesticide sprays.

The plants were allowed to runner freely with occasional cultivation to train the stolons into matted rows. For both soil treatments, the total numbers of runner plants per plot were counted in October on the fumigated and nonfumigated plots. The following year, all fruit that were at least $60 \%$ red were harvested weekly and weighed. One month after the last picking, 20 genotypes were selected whose yield appeared to cover the range of performance on nonfumigated soils. From two fumigated and two nonfumigated plots, five to 10 randomly selected plants of each genotype were dug, put in plastic bags and taken to the laboratory. The roots were shaken to remove the soil and a visual assessment was made of root density and overall root health. A rating scale of 1 to 5 was used, with 1 representing the most severe symptoms (very few fine roots, black structural roots), and 5 representing little evidence of disease (many fine roots, healthy structural roots). The occurrence of lesions on secondary and feeder roots was also noted. The number of crowns per plant was counted, and a random sample of 10 crowns per plot was split open and any discoloration noted. The sampled plants were then divided into root, crown and leaf tissue and dried at $65^{\circ} \mathrm{C}$ for $5 \mathrm{~d}$ to measure dry matter accumulation.

The incidence of plant parasitic nematodes was assessed in 1-g collective root samples and $100-\mathrm{cm}^{3}$ rhizosphere soil samples from each plot. Nematodes were extracted from the root tissue using the flask-shaker method (Bird, 1971) and from soil with a modified centrifugal flotation procedure with nested sieves with 710 - and $37-\mu \mathrm{m}$ openings and identified by species (Jenkins, 1964). To determine the identity of root-infecting pathogens, five plants were randomly collected from each fumigated and nonfumigated block (20 plants total per treatment). The root systems were washed in running tap water and visually inspected. Three to five roots with visible lesions were selected per plant, surface-sterilized in $1 \% \mathrm{NaOCl}$ for $1 \mathrm{~min}$, rinsed twice in sterile distilled water, and blotted dry between sterile paper towels. They were cut into $1-\mathrm{cm}$ long sections and five pieces per plate were incubated on a selective medium [200 mL V-8 juice (Campbell Soup Co., Camden, N.J.), $3.4 \mathrm{~g}$ agar, $0.6 \mathrm{~g} \mathrm{CaCO}_{3}$, $30 \mathrm{mg}$ ampicillin, $6 \mathrm{mg}$ rifampicin, and $20 \mathrm{mg}$ PCNB (pentachloronitrobenzene)]. Fungi were identified based on culture and spore morphology.

Model variance components due to genotype, fumigation, germplasm source, genotype $\times$ fumigation treatment interaction and 
error were estimated as in Larson and Shaw (1995). The analysis of variance was conducted using the SAS program (SAS Institute, Cary, N.C.)

\section{Results and Discussion}

Significant differences $(P \leq 0.05)$ were observed among the germplasm sources for runner production, fruit weight, and total yield (Table 2). The eastern cultivars had the highest average yields, while the elite hybrids produced the most runners (Table 3). Fruit of the eastern and California cultivars had about the same average weight, but were heavier than those of the elite hybrids.

Fumigation resulted in significant increases in runner production, fruit weight, and total yield of all genotypes, and there

Table 1. Strawberry genotypes evaluated on fumigated and nonfumigated soil.

\begin{tabular}{|c|c|}
\hline Genotype & Origin \\
\hline \multicolumn{2}{|c|}{ California cultivars } \\
\hline Chandler & Univ. Calif. \\
\hline Fern & Univ. Calif. \\
\hline Seascape & Univ. Calif. \\
\hline Selva & Univ. Calif. \\
\hline \multicolumn{2}{|r|}{ Eastern cultivars } \\
\hline Allstar & USDA-Md. \\
\hline Annapolis & Agr. Can.-N.S. \\
\hline Earliglow & USDA-Md. \\
\hline Glooscap & Agr. Can.-N.S. \\
\hline Honeoye & N.Y.-Agr. Exp. Sta. \\
\hline Jewel & N.Y.-Agr. Exp. Sta. \\
\hline Kent & Agr. Can.-N.S. \\
\hline Midway & USDA-Md. \\
\hline Redchief & USDA-Md. \\
\hline Surecrop & USDA-Md. \\
\hline Tribute & USDA-Md. \\
\hline \multicolumn{2}{|c|}{ F. virginiana hybrids } \\
\hline DHL 1032 & Glooscap x Montreal River 10 \\
\hline DHL 1336 & Chandler x Montreal River 10 \\
\hline DHL 3277 & Totem x LH 35-15 \\
\hline MSU 170-2 & Glooscap x Montreal River 10 \\
\hline MSU 187-1 & Glooscap x LH 10-6 \\
\hline MSU 213-2 & Cardinal x RH 18 \\
\hline MSU 245-2 & Tribute $\mathrm{x}$ Montreal River 10 \\
\hline MSU 245-4 & Tribute $\times$ Montreal River 10 \\
\hline MSU 248-1 & 251DN107 x Montreal River 10 \\
\hline MSU 257 & Seascape x LH 28-1 \\
\hline
\end{tabular}

were no significant source $\times$ fumigation interactions except for fruit weight (Table 2). Plants in nonfumigated soils had an average of $43 \%$ fewer runners, $18 \%$ smaller fruit, and $46 \%$ lower yields than did plants on fumigated soil. While fumigation did not significantly increase the dry weights of plants, there was a trend toward smaller plants in the nonfumigated soil (data not shown). Overall mortality was low $(<5 \%)$ on both fumigated and nonfumigated soil, suggesting that any effects of fumigation were due to the control of soil-borne organisms with sublethal effects.

Examinations of the roots revealed symptoms of the black root rot complex, including black, rotted structural roots, few fine roots, and brown lesions on younger roots. These were found primarily on plants grown without fumigation; however, limited disease symptoms were observed on plants from fumigated plots as well. This is not surprising, since the root samples were taken in the second year, and reinoculation may have occurred from the treated plots, by soil movement from the nonfumigated plots, by adherence of soil particles at planting, or by both.

Plants grown on nonfumigated soil had on average $27 \%$ more crown and $49 \%$ more root discoloration than did plants on fumigated soil. The visual root rating scores were significantly lower $(22 \%)$ for plants grown on nonfumigated soil (Tables 2 and 3 ). The cause of crown discolorations was not determined, but the most commonly isolated pathogens from diseased roots were Pythium sp., Rhizoctonia sp., and Idriella lunata P.E. Nelson \& K. Wilh. All of these pathogens have been reported to contribute to the black root rot complex (Maas, 1998). High densities of the rootknot nematode (M. hapla) were also found in roots of plants grown in nonfumigated soils, but incidence of the root lesion nematode [Pratylenchus penetrans (Cobb) Filipjev \& Schuurmans Stekhoven] was negligible.

These data mirror what has previously been described in California (Larson and Shaw, 1995, 1996; Shaw and Larson, 1999). The presence of severe black root rot symptoms and soil-borne pathogens commonly associated with this disease, as well as high levels of the root-knot nematode in the non- fumigated plots, appeared to be associated with the reduced productivity of the strawberry cultivars and genotypes in this trial. We noted a reduction in dry root weight on nonfumigated plots, although it was not as dramatic as has been described previously (Fort and Shaw, 1998; Yuen et al., 1991). In the study by Yuen et al. (1991), black root rot was the only disease of significance. However, the pathogen spectrum was somewhat different from ours, in that Cylindrocarpon destructans (Zinnsmeister) Scholten and Pythium sp. were the most common fungi isolated from diseased plants. No nematode analysis was conducted in their study.

Source $\times$ environment interaction was nonsignificant for most of the production traits at the $P \leq 0.05$ level, but source $\times$ environment interaction was significant for fruit weight (Table 2). In addition, the source $\times$ environment interaction for yield and runners was significant at the $P \leq 0.10$ level. Overall, the $F$. virginiana hybrids performed better without fumigation than did eastern or California cultivars (Table 3). This suggests that at least some resistance to black root rot may exist in $F$. virginiana that can be used to improve our current, highly susceptible cultivars. A broader screen of native resistance is probably warranted.

\section{Literature Cited}

Bird, G.W. 1971. Influence of incubation solution on the rate of recovery of Pratylenchus brachyurus from cotton roots. J. Nematol. 3:378-385.

Fort, S.B. and D.V. Shaw. 1998. Phenotypic correlations between root and shoot traits of strawberry in fumigated and nonfumigated soils. HortScience 33:222-224.

Gleason, M.L., G.R. Nonnecke, and C.D. Fear. 1989. Plant growth and yield of day-neutral and Junebearing strawberry cultivars in response to soil fumigation. Adv. Strawberry Prod. 8:51-52.

Hancock, J.F., P.W. Callow, A. Dale, J.J. Luby, C.E. Finn, S.C. Hokanson, and K.E. Hummer. 2001. From the Andes to the Rockies: Native strawberry collection and utilization. HortScience. (In press.)

Hancock, J.F., A. Dale, and J. Luby. 1993. Should we reconstitute the strawberry? Acta Hort. 348:85-93.

Jenkins, W.F. 1964. A rapid centrifugal-flotation

Table 2. Mean squares for productivity, vegetative growth, and disease ratings of strawberry cultivars and hybrids grown with and without preplant fumigation in Onondaga, Mich.

\begin{tabular}{|c|c|c|c|c|c|c|c|}
\hline Source & $\begin{array}{c}\text { Yield } \\
\text { (g/plant) }\end{array}$ & $\begin{array}{l}\text { Fruit wt } \\
\text { (g/fruit) }\end{array}$ & $\begin{array}{c}\text { Runners } \\
\text { (no./plant) }\end{array}$ & $\begin{array}{c}\text { Crowns } \\
\text { (no./plant) }\end{array}$ & $\begin{array}{l}\text { Root } \\
\text { rating }^{\mathrm{z}}\end{array}$ & $\begin{array}{c}\text { Roots } \\
\text { discolored }(\%)\end{array}$ & $\begin{array}{c}\text { Crown } \\
\text { discolored }(\%)\end{array}$ \\
\hline$\overline{\text { Fumigation }(\mathrm{F})}$ & $6,483,872^{* *}$ & $78.4^{* *}$ & $10,225^{*}$ & 1.1 & $12.9^{* *}$ & $195.3^{* *}$ & $1,708.3^{*}$ \\
\hline Block/F & 479,372 & 6.3 & 1,060 & $7.3^{*}$ & 1.2 & 1.4 & 86.0 \\
\hline Germplasm source $(\mathrm{S})$ & $1,605,017^{* *}$ & $378.8^{* * *}$ & $44,120^{* *}$ & 0.9 & 0.9 & 1.1 & $1,756.3^{* *}$ \\
\hline $\mathrm{F} \times \mathrm{S}$ & 552,918 & $12.7^{* *}$ & 3,958 & 3.8 & 2.3 & 11.4 & 101.9 \\
\hline Genotype (G/S) & $840,227^{* *}$ & $21.0^{* * *}$ & 2,115 & 2.4 & $2.2^{*}$ & 6.7 & 231.1 \\
\hline $\mathrm{F} \times \mathrm{G} / \mathrm{S}$ & 213,781 & 2.3 & 1,456 & 1.4 & 1.0 & 6.8 & 269.5 \\
\hline Error & 191,054 & 2.5 & 1,461 & 1.7 & 0.9 & 7.6 & 278.2 \\
\hline$\sigma^{2}$ & $191,054(49)^{\mathrm{y}}$ & $2.5(14)$ & $1,460.6(43)$ & $1.7(83)$ & $0.9(66)$ & $7.6(94)$ & $278.2(80)$ \\
\hline$\sigma_{\mathrm{fxs}}^{2}$ & $20,439(5)$ & $0.8(4)$ & $201.6(6)$ & $0.1(7)$ & $0.1(8)$ & $0.4(5)$ & $0.0(0)$ \\
\hline$\sigma_{g / s}^{2}$ & $156,612(40)$ & $4.7(25)$ & $167.7(5)$ & $0.2(10)$ & $0.3(22)$ & $0.0(0)$ & $0.0(0)$ \\
\hline$\sigma_{\mathrm{fxg} / \mathrm{s}}^{2}$ & $11,363(3)$ & $0.0(0)$ & $0.0(0)$ & $0.0(0)$ & 0.1 (4) & $0.0(0)$ & $0.0(0)$ \\
\hline$\sigma_{p}^{2}$ & 392,295 & 18.5 & $3,412.6$ & 2.0 & 1.4 & 8.0 & 346.5 \\
\hline
\end{tabular}

${ }^{z}$ Scale: 1 = very few fine roots, structural roots black; 5 = many fine roots, structural roots healthy.

${ }^{y}$ Values in parentheses are percentages of the total phenotypic variance due to random effects, $\sigma_{\mathrm{p}}^{2}$; variance component values labeled 0 where negative.

${ }^{*},{ }^{* *}$ Significant at $P \leq 0.05$ or 0.01 , respectively. 
Table 3. Effects of preplant soil fumigation on productivity and vegetative growth of strawberry cultivars in Onondaga, Mich.

\begin{tabular}{|c|c|c|c|c|c|c|c|c|}
\hline \multirow{2}{*}{ Observation } & \multicolumn{8}{|c|}{ Germplasm source } \\
\hline & \multicolumn{2}{|c|}{ California } & \multicolumn{2}{|c|}{ Eastern } & \multicolumn{2}{|c|}{ Hybrid } & \multicolumn{2}{|c|}{ Mean } \\
\hline Yield (g/plant) & $882 \pm 542^{y}$ & $171 \pm 99$ & $1350 \pm 126$ & $696 \pm 376$ & $913 \pm 646$ & $649 \pm 382$ & $1086 \pm 576$ & $597 \pm 439$ \\
\hline Runners/plant & $29.3 \pm 9.8$ & $20.6 \pm 110.7$ & $33.7 \pm 11.3$ & $23.5 \pm 13.6$ & $120.0 \pm 54.3$ & $69.9 \pm 23.8$ & $71.7 \pm 66.8$ & $43.7 \pm 33.4$ \\
\hline Crowns/plant & $3.3 \pm 1.2$ & $2.2 \pm 0.7$ & $3.3 \pm 0.8$ & $3.0 \pm 1.3$ & $2.7 \pm 0.8$ & $2.9 \pm 0.7$ & $3.0 \pm 1.2$ & $2.9 \pm 1.5$ \\
\hline Root rating $^{x}$ & $3.6 \pm 0.5$ & $2.1 \pm 1.0$ & $2.8 \pm 1.2$ & $2.6 \pm 0.9$ & $3.4 \pm 0.7$ & $2.6 \pm 1.0$ & $3.2 \pm 1.1$ & $2.5 \pm 1.1$ \\
\hline Roots discolored (\%) & $2.5 \pm 0.9$ & $6.5 \pm 2.4$ & $2.4 \pm 0.8$ & $6.4 \pm 2.1$ & $3.8 \pm 1.9$ & $5.7 \pm 2.1$ & $3.1 \pm 2.3$ & $6.1 \pm 3.0$ \\
\hline
\end{tabular}

${ }^{2}$ The symbols - and + indicate no soil fumigation and preplant soil fumigation with $392 \mathrm{~kg} \cdot \mathrm{h}^{-1}$ of 2 methyl bromide : 1 chloropicrin (by weight), respectively.

${ }^{y}$ Mean \pm SD

${ }^{\mathrm{x}}$ Scale: 1 = very few fine roots, black structural roots; 5 = many fine roots, healthy structural roots.

technique for extracting nematodes from soil. Plant Dis. Rptr. 48:692.

Keefer, R.F., C.E. Hickman, and R.E. Adams. 1978. The response of strawberry yields to soil fumigation and nitrogen fertilization. HortScience 13:51-52.

Larson, K.D. and D.V. Shaw. 1995. Relative performance of strawberry genotypes on fumigated and nonfumigated soil. J. Amer. Soc. Hort. Sci. 120:274-277.

Larson, K.D. and D.V. Shaw. 1996. Soil fumigation, fruit production, and dry matter partitioning of field-grown strawberry plants. J. Amer. Soc. Hort. Sci. 121:1137-1140.

Maas, J. L. (Ed.). 1998. Compendium of strawberry diseases. 2nd. ed. APS Press, St. Paul, Minn. Shaw, D.V. and K.D. Larson. 1999. A meta-analysis of strawberry yield response to preplant soil fumigation with combinations of methyl bromide-chloropicrin and four alternate systems. HortScience 34:839-845.

Strang, J.G., D.D. Archbold, J.R. Hartman, and J.W. Hendrix. 1985. Strawberry cultivar yield response to soil fumigation. Adv. Strawberry Prod. 4:36-38.

Wing, K.B., M.P. Pritts, and W.F. Wilcox. 1995a. Biotic, edaphic and cultural factors associated with strawberry black root rot in New York. HortScience 30:86-90.

Wing, K.B., M.P. Pritts, and W.F. Wilcox. 1995b.
Field resistance of 20 strawberry cultivars to black root rot. Frt. Var. J. 49:94-98.

Xiao, C.L., and J. M. Dunaway. 1998a. Bacterial population responses to soil fumigation and their effects on strawberry growth. Phytopathology 88:S100.

Xiao, C.L., and J. M. Dunaway. 1998b. Frequency of isolation and pathogenicity of fungi on roots of strawberry in fumigated and nonfumigated soils. Phytopathology 88:S100.

Yuen, G.Y., M.N. Schroth, A.R. Weinhold, and J.G. Hancock. 1991. Effects of soil fumigation with methyl bromide and chloropicrin on root health and yield in strawberry. Plant Dis. 75:416-420. 